\title{
Glottis Neoplasm
}

National Cancer Institute

\section{Source}

National Cancer Institute. Glottis Neoplasm. NCI Thesaurus. Code C4425.

A benign or malignant neoplasm that affects the glottic area of the larynx. 